\title{
Mitigating Overloading Vehicle Effects in Relation to the Liddle Power Equations for Designing Road Pavement Lifespan
}

\author{
Ari Sandhyavitri, Arief Aditya, and Muhamad Yusa
}

\begin{abstract}
This paper objective is to mitigate to what extent the Liddle empirical formula (which the initial power equation of $4^{\text {th }}$ order) may suit in designing road pavement lifespan for overloading vehicle roads. A case study was conducted in the Meredan highway, Siak, Riau, Indonesia. It was identified that the Truck Factor $(\mathrm{TF})>1$ in this road. During 3 years project operation, the pavement condition has been deteriorated (Road Surface Index fail, IPf=1.5). Hence, the road was proven to be a failure before reaching its designated project lifespan (10 years). This study conducted various calculations by adjusting the Liddle empirical exponential formula (from power equation of $4^{\text {th }}$ to $6^{\text {th }}$ order) in order to fulfill the pavement lifespan which was capable to serve the overloading traffic loads in this road. This research has identified that there is a need to adjust the Liddle empirical formula by power equation of $6^{\text {th }}$ order to accommodate the current overloading vehicles.
\end{abstract}

Index Terms-overloading, pavement, Liddle formula, Equivalent Axle Load (EAL), Cumulative Equivalent Standard Axle (CESA) load.

\section{INTRODUCTION}

$T^{1}$ he traffic flow at the Meredan Junction passing Sultan Syarif Hasyim's Bridge at Siak, Riau Province, Indonesia has been dominated by heavy vehicles [1]. The types of heavy vehicles were mainly encompassing trucks and trailers carrying wood, palm oil, and CPO (Figure 1a). These heavy vehicles were considered as overloading vehicles with the total axle load were more than a standard axle load of road class III ( 8 tons). The wheel axle load data were obtained from the Siak Transportation Department and Dirjen Bina Marga Department $[1,2]$. The traffic flow of this road was also relatively heavy (Figure 1b). The location of

A. Sandhyavitri is with the Department of Civil Engineering, Universitas Riau, 28293, Pekanbaru, Riau, Indonesia (e-mail: author@email.org)

A. Aditya is with the Department of Civil Engineering, Universitas Islam Riau, 28293, Pekanbaru, Riau, Indonesia

M. Yusa is with the Department of Civil Engineering, Universitas Riau, 28293, Pekanbaru, Riau, Indonesia the study area is shown in Figure 2.

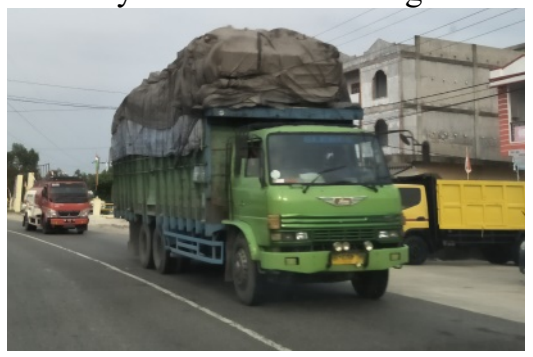

Fig. 1a. Overloading vehicles passing the Meredan roads, Siak, Indonesia

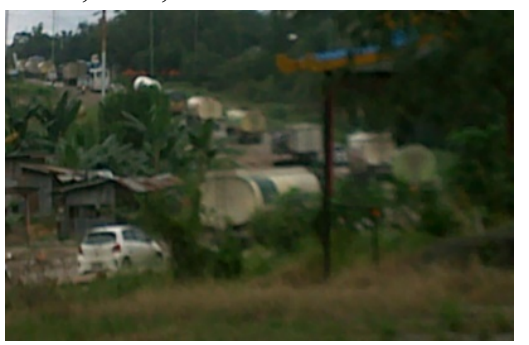

Fig. 1b. The traffic flow conditions.

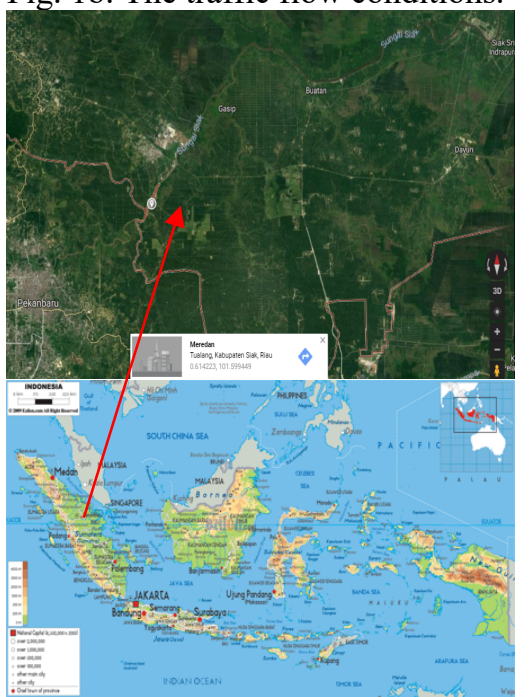

Fig. 2. Research location in Meredan, Siak, Indonesia (goole.co.id, 2018)

The road was fully operated in 2010 and it designated project lifespan would be 10 years (up to 2019). Unfortunately, in 2013 the road surface condition has been deteriorated (Figure 3) and the $\mathrm{IP}_{\mathrm{f}}$ reached 1.5. Figure 3 shows the damage of the Meredan pavement condition after approximately 3 years of the project operation which confirmed that 
the actual design lifespan was shorter than it should be.

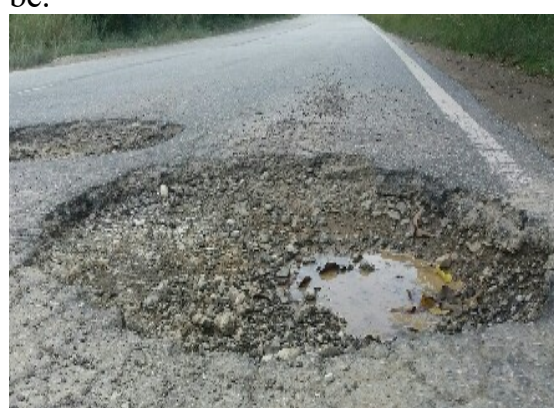

Fig. 3. Road damage in Meredan, Siak, Indonesia, 2015.

It was acknowledged that, various pavement calculations have been reviewed in many publications and literatures, but the common applications of the pavement thickness design in Indonesia have been empirical methods $[3,4,5]$.

The component analysis method 1987 was used to conduct the pavement design which was then replaced by the Bina Marga flexible pavement design Pt.T-01-2002-B. This was based on the AASHTO 1993 method. The pavement design manual No. $22.2 / \mathrm{KPTS} / \mathrm{Db} / 2012$ was then latterly issued as a compliment to the Pt.T-01-2002-B Manual [3, 4, 5].

The existing Liddle's formula for the equivalent axle load (EAL) calculation uses the power equation of $4^{\text {th }}$ order $[6,7,8]$. As the fact, the overload vehicles passing the Meredan road are very common then as a consequence the road lifespan might be shorter. It was assumed that the existing soil, subbase, and pavement layers were in good condition and were constructed according to the standard [5].

Under the standard design condition, most of the engineers in Indonesia have calculated pavement road design using an empirical method based on the Bina Marga design manual of Pt.T-01-2002-B.

The results of the implementation of this manual, in general, have satisfied the objectives of road stakeholders, except for a certain condition of the road with overloading vehicle and truck factor $>1$. Under this circumstance, the condition of an initial road design (for example 10 years) becomes shorter. The pavement surface index will be degraded before reaching its lifespan $[9,10.11,12,13,14]$.

\section{LITERATURE REVIEW}

\section{A. Equivalent Single Axle Load (ESAL)}

The Equivalent Single Axle Load (ESAL) is a ratio of damage factor value caused by the single axle load (with a standard single axle load of 8.16 ton or $18.000 \mathrm{lbs})[13,14,15]$. The ESAL of each configuration of the axle load is calculated based on the distribution of the vehicle wheel loads e.g. for a single axle wheel configuration is:

ESAL of single axle single wheel (front

$$
\text { wheel })=\left\lceil\frac{1}{5.40}\right]^{4}=0.0012
$$

ESAL of single axle single wheel (rear wheel)

$=\left[\frac{1}{5.40}\right]^{4}=0.0012$

As the single axel front wheel and rear wheel are similar, thus it's ESAL (with using Liddle empirical power equation of $4^{\text {th }}$ order $)=0.0012$. This study investigated the applicability of this Liddle empirical power equation of $4^{\text {th }}$ order for the Meredan overloading road, in Siak, Indonesia.

\section{B. Truck Factor (TF)}

The truck factor (TF) is one of the main causes of pavement deformation and pavement damage [16, 17]. These are determined by the ratio of the equivalent standard axle load to the average number of traffic loads.

$\mathrm{TF}=\frac{E S A L}{N}$

Where

TF : Truck Factor

ESAL : Equivalent Standard Axle Load (Total)

$\mathrm{N}$ : Average number of traffic load.

A road was categorized as an overloaded one when the $\mathrm{TF}>1$. Hence, this study has investigated whether the location of this study was overloaded road or not.

\section{RESULTS}

\section{A. Traffic volume for the design lane}

This study compiled daily traffic volume in 2010 and 2013. The following table shows the average daily traffic volume in 2010 and 2013.

TABLE 1

THE AVERAGE DAILY TRAFFIC VOLUME (LHR) IN 2010 AND 2013 IN MEREDAN ROAD.

\begin{tabular}{lcccc}
\hline Vehicle type & \multicolumn{2}{c}{ Number } & \multicolumn{2}{c}{$\begin{array}{c}\text { Average daily } \\
\text { traffic volume }\end{array}$} \\
\cline { 2 - 5 } & 2010 & 2013 & 2010 & 2013 \\
\hline Private car & 546 & 621 & 546 & 621 \\
\hline Small bus & 18 & 36 & 18 & 36 \\
\hline Big bus & 10 & 14 & 10 & 14 \\
\hline Truck 2 axle & 296 & 314 & 296 & 314 \\
\hline Truck 3 axle & 198 & 226 & 198 & 226 \\
\hline Truck 5 axle & 13 & 20 & 13 & 20 \\
\hline Trailer & 4 & 6 & 4 & 6 \\
\hline & & Total & 1085 & 1237 \\
\hline
\end{tabular}

Source: the Siak Transportation Department, 2015

Based on Table 1, it can be calculated that the projected traffic growth (i) was as follow:

Daily traffic volume (LHR) year

$\mathrm{n}=$ base LHR $(1+\mathrm{i})^{\mathrm{n}}$

Daily traffic volume

(LHR) 2010

LHR 2013

LHR $2010(1+\mathrm{i})^{3}$

$1085(1+i)^{3}$

$=1085$ vehicle $/$ day

$=1237$ vehicle/day

$=$ LHR 2013

$=1237$ 


$$
\begin{aligned}
(1+\mathrm{i})^{3} & =1.140 \\
\mathrm{i} & =(\sqrt[3]{1,140})-1 \\
\mathrm{i} & =(1.04-1) \times 100 \% \\
\mathrm{i} & =4 \% \text { (per year) }
\end{aligned}
$$

Thus the projected traffic growth in this road was $4 \%$ per year.

C. Equivalent Standard Axle Load (ESAL) calculation using Liddle exponential $4^{\text {th }}$ order

The Equivalent Standard Axle Load (ESAL) or number of load repetitions (which was converted to an axle load standard) was calculated for each type of vehicle. The following Table 2 shows an example of the ESAL of loaded vehicles using an initial

\begin{tabular}{|c|c|c|c|c|c|c|c|c|c|c|c|c|c|c|c|c|}
\hline \multirow{4}{*}{10} & \\
\hline & \multirow{3}{*}{ Fatiktidips } & \multirow{3}{*}{ 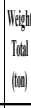 } & \multicolumn{3}{|c|}{1.61} & & \multicolumn{3}{|c|}{ 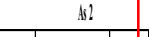 } & & \multicolumn{4}{|c|}{ 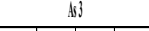 } & \multirow{3}{*}{\begin{tabular}{|l|} 
Bil \\
Proer \\
Gavain
\end{tabular}} & \\
\hline & & & " lital & te trat & & Rit & " Indull & & & & & & & & & \\
\hline & & & (iv) & (tive) & alie & & (iv) & & Alite & & (ii) & (in) & Alle & & & \\
\hline 1 & linthithite & 200 & 测 & 1 & AST & 0.012 & $S_{H}$ & 1 & SHAS & 0,002 & & & & & 4 & and \\
\hline ? & Serdbs & 9.17 & 粗 & 262 & ASI & $0.6,64$ & 69.1 & 5. & SADI & 0.5.54 & & & & & 4 & 02680 \\
\hline 1 & biglis & 9011 & 荘 & 3.6 & AST & 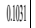 & 形 & 5,55 & SADO & 0200 & & & & & 4 & 13968 \\
\hline 4 & 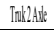 & 13.30 & 消U & 459) & AST & (152) & $6 f_{1}$ & 81 & SHDD & $1015 \|$ & & & & & 4 & 1495 \\
\hline j & Tnsis & X:O & $8 \%$ & $10 \mathrm{AA}$ & AST & 10002 & $\mathbb{Z}_{1}$ & 1.6 & $D, D D$ & |ikan|| & & & & & 4 & ind \\
\hline 6 & Trish Athe & $4.8 \%$ & 181 & 8.9 & SIST & 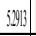 & 1818 & $\mathbb{R} 10$ & $\$ \$ N$ & 5983 & 的I & 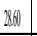 & ADT & 6770 & 40 & (IS3id ) \\
\hline 1 & Trlltit & 9886 & $13 \%$ & INH & AST & 199000 & 39 & מא & $D A D D$ & (16)200 & 20 & $4(1,2)$ & ADTI & 148607 & 4 & S6/288 \\
\hline
\end{tabular}
power equation of $4^{\text {th }}$ order.

TABLE 2

ESAL OF AN INITIAL POWER EQUATION OF $4^{\mathrm{TH}}$ ORDER

This table uses a standard vehicle axle load. For example, the distribution of truck 5 axle load was as follow; every single axle 1 and 2 compromising $18 \%$ of load, thus the distribution of axle 3 would be $100 \%-(18 \% \times 2)=64 \%$. Using the ESAL equation with power equation of $4^{\text {th }}$ order as follow;

ESAL (loaded vehicle) $=\left[\frac{8.19}{5.40}\right]^{4}+\left[\frac{8.19}{5.40}\right]^{4}+\left\lceil\frac{28.60}{18.45}\right]^{4}=$ 16.3566 (Table 2)

Based on vehicle volume data in 2013, the ESAL total per day is presented in the following table

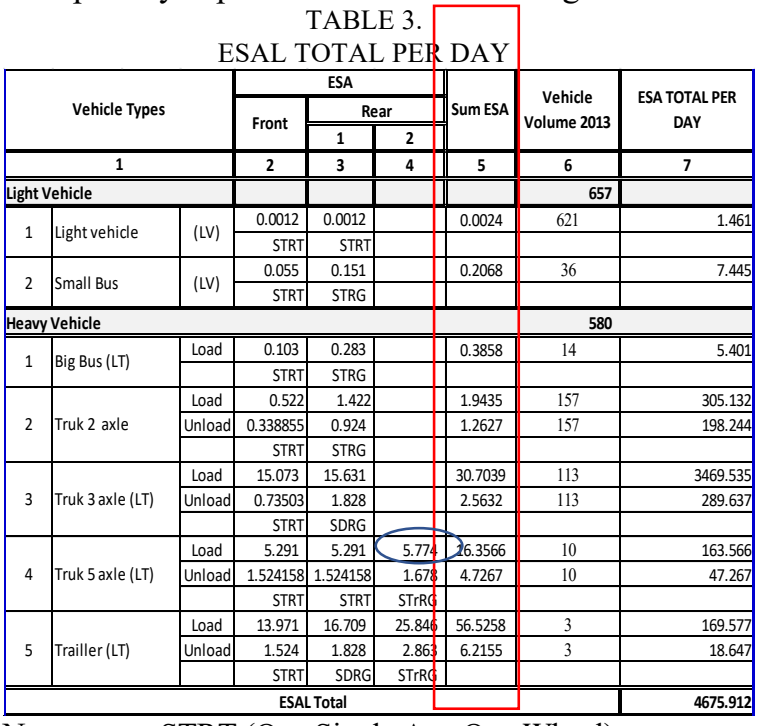

Notes :
STRG (One Single Axe Tandem Wheels)SDRG (Double Axes Tandem Wheels)
STrRG (Triple Axes Tandem Wheels)

ESAL total for this Meredan road per day was 4,675.9 (Table 3), hence in a single year ESAL = 4,675.9 /day x 365 day $=1,706,707.95$ axle load standard (2013). This ESAL will be used in the calculation of Cumulative Equivalent Standard Axle (CESA) load.

\section{Equivalent Standard Axle (ESA)}

Based on the Siak Transportation Department (2015) it was stated that in 2010, the ESA of this road was at the average of 4039.3 vehicles. As ESA (in Indonesia is also known as LEP and W18) can be calculated as follow:

ESA (Indonesia $=$ LEP) in $2010 \quad=4039.3$

Road design life $(\mathrm{n})=10$ years

Traffic growth (i) $\quad=4 \%=0.04$ (Based on the calculation of (i) above).

Hence, ESA/day $(\mathrm{i}=0)=\left[\operatorname{LEP}(1+\mathrm{i})^{\mathrm{n}}\right]$

$$
=\left[4039.34(1+0,04)^{0}\right]
$$$$
=4039.34
$$

$$
\mathrm{ESA} / \text { year }=[(\mathrm{ESA} / \text { day }) \times 365]
$$

$$
\begin{array}{r}
=[4039.34 \times 365] \\
=1,474,360.21
\end{array}
$$

Then it was calculated the cumulative Equivalent

\begin{tabular}{|c|c|c|c|}
\hline Year & $\begin{array}{c}\text { ESA/day } \\
{[\operatorname{LEP}(1+} \\
\text { i }) n]\end{array}$ & $\begin{array}{c}\text { ESA/year } \\
{[(\text { ESA/day)x }} \\
365]\end{array}$ & CESA \\
\hline 2010 & $4,039.34$ & $1,474,360.21$ & $1,474,360.21$ \\
\hline 2011 & $4,200.92$ & $1,533,334.62$ & $3,007,694.84$ \\
\hline 2012 & $4,368.95$ & $1,594,668.01$ & $4,602,362.84$ \\
\hline 2013 & $4,543.71$ & $1,658,454.73$ & $6,260,817.57$ \\
\hline 2014 & $4,725.46$ & $1,724,792.92$ & $7,985,610.49$ \\
\hline 2015 & $4,914.48$ & $1,793,784.63$ & $9,779,395.12$ \\
\hline 2016 & $5,111.06$ & $1,865,536.02$ & $11,644,931.14$ \\
\hline 2017 & $5,315.50$ & $1,940,157.46$ & $13,585,088.60$ \\
\hline 2018 & $5,528.12$ & $2,017,763.76$ & $15,602,852.36$ \\
\hline 2019 & $5,749.24$ & $2,098,474.31$ & $17,701,326.67$ \\
\hline \multicolumn{3}{|c|}{ AE 18 Kip SAL } & $17,701,326.67$ \\
\hline
\end{tabular}
Standard Axle (CESA) by multiplication of ESA $x$ 365 days. Table 4 shows the calculation results of CESA from 2010-2019 (as an initial projected road design lifespan).

TABLE 4.

THE CUMULATIVE EQUIVALENT STANDARD AXLE (CESA) LOAD 2010-2019

Hence the ESA $=4,675.9$ /day was reached in the period of 2013-2014. As it was reported that, in 2013-2014 (3-4 years project operation) the road pavement condition has been deteriorated $\mathrm{IPf}=1.5$ ). However, it was designated that the project design 
life span would be 10 years (up to 2019) with the total CESA in 2019 of 17,701,326.67.

Hence, this study mitigated the degradation of this road with the assumption that there was an effect of overloading vehicle (truck factor) on the Liddle power equations for designing the road pavement lifespan.

Truck Factor (TF)

$$
\begin{aligned}
& \mathrm{TF}=\frac{E S A L}{N} \\
& \mathrm{TF}=\frac{4.675,912}{580}=8.0619>1
\end{aligned}
$$

As the TF is higher than one $(>1)$, then the road section is considered overloaded. It was identified that heavy vehicles in this road section were higher than the standard stated in the highway design capacity (HCM) manual 1983, 1987 and 1997 (for sub-urban roadway) $[5,13,18]$.

The numerical calculation used to calculate the existing cumulative traffic flow. This is presented as follow;

$$
W_{t}=W_{18} \times \frac{(1+g)^{n}-1}{g}
$$

Where
$\mathrm{W}_{\mathrm{t}}=$ Sum of the cumulative axle load within the designated design lifespan

$\mathrm{W}_{18}=$ cumulative axle load for one year

$\mathrm{n}=$ designated design lifespan $(\mathrm{n})$

$\mathrm{g}=$ traffic growth $(\%)$.

\section{E. Backward Analysis for the Cumulative Equivalent Standard Axle (CESA)}

As the Meredan road pavement condition in the field was already deteriorated in 2013 (not in 2019), there was necessary to conduct the backward analysis by shifting the order of the Liddle equation which will closely matche with CESA of $17,701,326.67$.

Trial and error approaches were applied in the calculation $[19,20]$. It was tried initially by conducting calculation using of $4^{\text {th }}$ power exponential. The result was stated that the projected project lifespan was 10 years with CESA design of 17,701,326.67 (Table 4).

Then it was tried to apply $5^{\text {th }}$ power exponential in the calculation. The results were obtained as follow; the projected project life span was 7 years with CESA approximately 17,306,145. Again it was tried to apply the power exponential of $6^{\text {th }}$ order from the Liddle equation (Table 5).

\begin{tabular}{|c|c|c|c|c|c|c|c|c|c|c|c|c|c|}
\hline \multirow[b]{2}{*}{ No } & \multirow[b]{2}{*}{ Vehicle Types } & \multirow[b]{2}{*}{$\begin{array}{c}\text { Weight } \\
\text { (ton) }\end{array}$} & \multicolumn{2}{|r|}{ Axle 1} & & \multicolumn{2}{|r|}{ Axle 2} & & \multicolumn{3}{|c|}{ Axle 3} & \multirow{2}{*}{$\begin{array}{c}\text { Power } \\
\text { ESAL } \\
\text { Equatio } \\
\text { n }\end{array}$} & \multirow[b]{2}{*}{ Total ESAL 2010} \\
\hline & & & $\begin{array}{c}\% \text { Load } \\
(\%)\end{array}$ & $\begin{array}{c}\text { Axle Load } \\
\text { (ton) }\end{array}$ & ESAL & $\begin{array}{c}\% \\
\text { Load } \\
(\%) \\
\end{array}$ & $\begin{array}{l}\text { Axle } \\
\text { Load } \\
\text { (ton) }\end{array}$ & ESAL & $\begin{array}{c}\% \text { Load } \\
(\%)\end{array}$ & $\begin{array}{c}\text { Axle Load } \\
\text { (ton) }\end{array}$ & ESAL & & \\
\hline 1 & Private Vehicle & 2.00 & $50 \%$ & 1 & 0.00004 & $50 \%$ & 1 & 0.00004 & & & & 6 & 0.000081 \\
\hline 2 & Small Bus & 7.71 & $34 \%$ & 2.62 & 0.01305 & $66 \%$ & 5.09 & 0.05891 & & & & 6 & 0.071952 \\
\hline 3 & Big Bus & 9.01 & $34 \%$ & 3.06 & 0.03311 & $66 \%$ & 5.95 & 0.15030 & & & & 6 & 0.183411 \\
\hline 4 & Truck 2 Axle & 13.50 & $34 \%$ & 4.59 & 0.37715 & $66 \%$ & 8.91 & 1.69483 & & & & 6 & 2.07198 \\
\hline 5 & Truck 3 Axle & 38.00 & $28 \%$ & 10.64 & 58.51769 & $72 \%$ & 27.36 & 61.79964 & & & & 6 & 120.31734 \\
\hline 6 & Truck 5 Axle & 44.98 & $18 \%$ & 8.19 & 12.17141 & $18 \%$ & 8.19 & 12.17141 & $64 \%$ & 28.60 & 13.8745 & 6 & 38.21734 \\
\hline 7 & Trailler & 79.86 & $13 \%$ & 10.44 & 52.22043 & $35 \%$ & 27.82 & 68.30180 & $52 \%$ & 41.60 & 131.3959 & 6 & 251.91811 \\
\hline
\end{tabular}

TABLE 5.

ESAL OF TRIAL AND ERROR FOR POWER EQUATION OF $6^{\mathrm{TH}}$ ORDER.

For example, the distribution of truck 5 axle load was as follow;

ESAL (loaded vehicle) $=\left\lceil\frac{8.19}{5.40}\right\rceil^{6}+\left\lceil\frac{8.19}{5.40}\right\rceil^{6}+\left\lceil\frac{28.60}{18.45}\right\rceil^{6}=$ 38.217 (Table 5)

There is a significant change in ESAL for the initial calculation (Table 2) and the final calculation (Table 5). The final calculation of ESAL (Table 5), especially for trucks and trailers, become 2 to 5 times greater than those in the initial one. This calculation will be used for calculating the CESA (Table 6).

It was obtained that the CESA design became $17,708,448.39$ (Table 6) and it was almost similar to 17,701,326.67 (Table 4). It was also projected that the road pavement lifespan may be reached in 20132014 (with heavily damaging condition of IPf $=1.5$ ).

The table 6 and figure 4 demonstrated that, by utilizing the exponential $6^{\text {th }}$ order of the Liddle equation, it may yield CESA value of 17708448.39 in May 2013 (3 years 5 months) which is similar to
10 years of the designated project lifespan with CESA value of 17701326.67 of $4^{\text {th }}$ order of the Liddle equation for 2019.

TABLE 6

\begin{tabular}{|c|c|c|c|}
\hline Year & $\begin{array}{c}E S A / d a y \\
{[\operatorname{LEP}(1+i) n}\end{array}$ & $\begin{array}{c}\text { ESA/year } \\
\text { ESA/day)x 365] }\end{array}$ & CESA \\
\hline 2010 & $13,498.19$ & $4,926,838.92$ & $4,926,838.92$ \\
\hline 2011 & $14,038.12$ & $5,123,912.48$ & $10,050,751.39$ \\
\hline 2012 & $14,599.64$ & $5,328,868.97$ & $15,379,620.37$ \\
\hline May 2013 & $15,183.63$ & $5,542,023.73$ & $17,708,448.39$ \\
\hline 2013 & $15,183.63$ & $5,542,023.73$ & $20,921,644.10$ \\
\hline 2014 & $15,790.97$ & $5,763,704.68$ & $26,685,348.78$ \\
\hline 2015 & $16,422.61$ & $5,994,252.87$ & $32,679,601.65$ \\
\hline 2016 & $17,079.52$ & $6,234,022.98$ & $38,913,624.64$ \\
\hline 2017 & $17,762.70$ & $6,483,383.90$ & $45,397,008.54$ \\
\hline 2018 & $18,473.20$ & $6,742,719.26$ & $52,139,727.80$ \\
\hline 2019 & $19,212.13$ & $7,012,428.03$ & $59,152,155.83$ \\
\hline \multicolumn{3}{|c|}{ AE 18 Kip SAL } & $59,152,155.83$ \\
\hline
\end{tabular}

CESA VALUES USING THE $6^{\text {TH }}$ ORDER OF LIDDLE EQUATION 


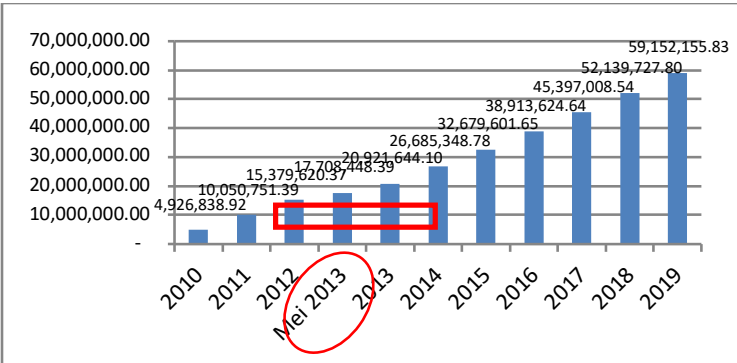

Fig. 4. Correlation of CESA and year

Figure 4 and 5 show that the CESA value of $17,708,448.39$ would be reached in the period of 3 years 5 months using Liddle power exponential equation of $6^{\text {th }}$ order.

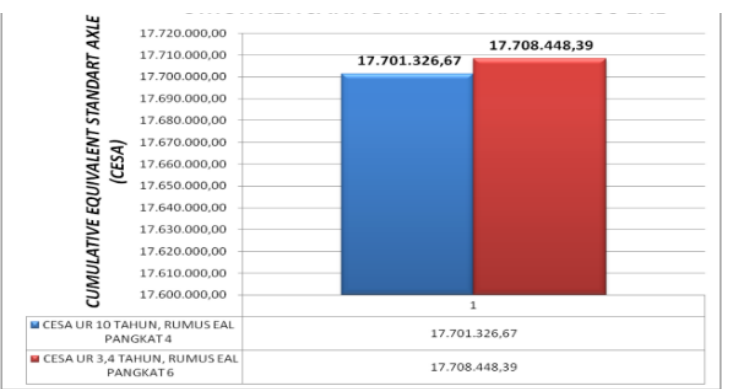

Fig. 5. CESA comparison of the $4^{\text {th }}$ and $6^{\text {th }}$ order of Liddle exponential equation

Both CESA values obtained from the trial and trial error analyses utilizing $4^{\text {th }}$ and $6^{\text {th }}$ order of the power exponential are similar to the projected project lifespans of 10 years and 3.4 years respectively.

\section{CONCLUSION}

The percentage of overloading vehicles in Meredan, Siak, Indonesia was $47 \%$ with the Truck Factor $(\mathrm{TF}=8.06)>1$, thus this road is categorized as overloading road. Hence the existing road pavements were deteriorating $(\mathrm{IPf}=1.5)$ before reaching the designated project lifespan of 10 years. Then this study has applied various Liddle's empirical equation for calculating the damage factor or EAL from the power exponential of the $4^{\text {th }}$ to $6^{\text {th }}$ order. This study identified that the road lifespan would be reached $\mathrm{IPf}=1.5$ in the period of 3.4 years of the project operation with the CESA of $17,708,448.39$. Hence it is recommended to consider the Liddle power exponential of $6^{\text {th }}$ instead of $4^{\text {th }}$ order for designing this road lifespan in Meredan, Riau, Indonesia.

\section{REFERENCES}

[1] The Siak Transportation Department, "Vehicle Loads Report for Siak Regency: Laporan Beban Lalu-lintas Kendaraan di Jalan, Kabupaten Siak”, Loose Report, Siak, Indonesia, 2015.

[2] Dirjen Bina Marga Dep. PU, "Survey of Maximum Axle Load Report: Laporan Hasil Survey Muatan Sumbu Terberat (MST) Kendaraan Truk Muatan Lebih Propinsi Riau”,
Direktorat Jenderal Bina Marga Departemen Pekerjaan Umum, Pekanbaru, 2002.

[3] AASHTO, "Interim Guide for Design of Pavement Structure 1972", American Association of State Highway \& Transportation Officials. Washington DC, USA, 1981.

[4] AASHTO, "Guide for design of pavement structures". American Association of State Highway \& Transportation Officials. Washington DC, USA, 1993.

[5] Dirjen Bina Marga Dep. PU, "Manual for Calculating of Flexible Pavement : Pedoman Penentuan Tebal Perkerasan Lentur Jalan Raya”, Direktorat Jenderal Bina Marga Departemen Pekerjaan Umum, Jakarta, 1983.

[6] A. Helmi, "Study of Damage Vehicle Factors: Kajian Tentang Formula Daya Rusak Kendaraan dari Beberapa Negara dan Isntitusi”, Lokakarya Forum Komunikasi Mahasiswa Teknik Sipil UIR,UNRI, dan UNILAK, 2000.

[7] E. Irmawan and I. B Mochtar, "Study of Equivalent Axe Loads in Relation of Road Damage : Studi Korelasi Angka Ekuivalensi As Kendaraan Ditinjau Dari Dampak Kerusakan Jalan Dengan Memasukkan Kondisi Subgrade Jalan". Skripsi S-1 ITS. Jurusan Teknik Sipil, FTSP-ITS, Surabaya,, 1990.

[8] G.A. Lubis, "Analyses of Axel Load Repetitions in Relation to Road Damage: Analisa Pengaruh Repetisi Baban Gandar Kendaraan Sebagai Faktor Perusak”, Tugas akhir Mahasiswa Teknik Sipil Universitas Riau, Pekanbaru, 2005.

[9] Y.H. Huang, "Pavement Analysis and Design". Prentice Hall, Englewood Cliffs, New Jersey, 1993.

[10] H.C. Hardiyatmo, "Road Maintenance : Pemeliharaan Jalan Raya", Gadjah Mada University Press, Yogyakarta, 2007.

[11] Perawitami, "Analyses of Pavement Thickness Versus Overloading Vehicle: Analisis Tebal Perkerasan Terhadap Muatan Berlebih Pada Ruas Jalan Duri - Dumai", Tugas Akhir Mahasiswa Teknik Jurusan Teknik Sipil, Universitas Islam Riau, Pekanbaru, 2006.

[12] Pd.T-05-2005-B, “A Manual of Designing Additional Pavement Layers: Pedoman Teknis Perencanaan Lapis Tambah Perkerasan Lentur" Dep. Permukiman dan Prasarana Wilayah, Jakarta, 2005.

[13] Pt.T-01-2002-B, "Flexible Pavement Thickness: Tebal perkerasan lentur AASHTO 93", Dep. Permukiman dan Prasarana Wilayah, Jakarta, 2002.

[14] K. Srikandi, "Analyses of Flexible Pavement Thickness: Analisa Tebal Perkerasan Akibat Beban Berlebih Pada Paket Peningkatan Ruas Jalan Kubang Raya Propinsi Riau", Tugas Akhir Mahasiswa Teknik Jurusan Teknik Sipil, Universitas Islam Riau, Pekanbaru, 2004.

[15] S. Sukirman, "Flexible Pavement: Perkerasan Lentur Jalan Raya", Nova, Bandung, 1999.

[16] S. Wiyono, "Calculating Benefit and Priority in Maintenance of Roads: Perhitungan Nilai Manfaat dan Prioritas penanganan jalan", UIR Press, Pekanbaru, 2009. 
[17] S. Wiyono, "Prediction of Flexible Pavement Damage: Prediksi Kerusakan Pada Perkerasan Lentur", UIR Press, Pekanbaru, 2009.

[18] Yayasan Badan Penerbit PU. A Manual of Road Pavement Design based on Component Analyses Method: Petunjuk Perencanaan Tebal Perkerasan Lentur Jalan Raya Dengan Metode Analisa Komponen, SKBI - 2.3.26.1987", UDC : 625.73 (02). Departemen Pekerjaan Umum, Jakarta, 1987.

[19] E.J. Yoder, and M.W. Witczak, "Principles of Pavement Design - 2nd Edition", John Willey \& Sons, USA, 1975.

[20] Z Lubis and I.B. Mochtar, "Evaluating of Damage Factors Equation: Evaluasi Rumusan Damage Factor (Equivalent Axle Load) Dalam Perancangan Sistem Perkerasan Lentur Jalan Raya Akibat Adanya Muatan Berlebihan". Jurnal Torsi. 19, 2008. 
